Revista Iberoamericana, Vol. LXXI, Núm. 211, Abril-Junio 2005, 521-537

\title{
MÁQUINAS, FICCIONES Y SOCIEDADES SECRETAS: CATERVA Y LA CIUDAD AUSENTE
}

POR

Marta Sierra

Kenyon College

En Adán Buenosayres (compuesta entre 1930 y 1948) Leopoldo Marechal recrea temas y personajes de la vanguardia argentina. En la novela el astrólogo Schultze, representación literaria del artista argentino Xul Solar, presenta la aparición de una figura alegórica que se denomina, como el lenguaje imaginario creado por él en los años veinte, el “Neocriollo”. Esta figura híbrida que combina cuerpo y tecnología es el futuro habitante de las pampas argentinas, un ser colosal que se describe de la siguiente manera:

Aquella forma estaba completamente desnuda: su caja torácica y su abdomen lucían una transparencia de Rayos X que dejaba ver el fino dibujo de los órganos internos; se mantenía de pie sobre una de sus piernas gigantes, y llevaba encogida la otra, como los flamencos del sur. Pero lo más asombroso era su cabezota envuelta en un halo radiante, sus ojos fosforescentes que giraban como faros en el extremo de dos largas antenas, su boca de saxofón y sus orejas como dos embudos giratorios que apuntaban ya a los héroes desconcertados. (180)

La descripción de este sujeto fantástico trae a la memoria una figura frecuente en las primeras décadas del siglo xx y que recorre las creaciones de Xul Solar: el hombremáquina. El Neocriollo, que concita el interés colectivo de los integrantes del grupo de vanguardia representado por la novela de Marechal, es una alegoría de la transición de una sociedad rural a una tecnológica. Expresa además la obsesión del período por el vitalismo corporal y la búsqueda de una productividad literaria que combine cuerpo y tecnología. Es además un texto manifiesto, una representación de un cuerpo y un discurso colectivo, y como tal el Neocriollo puede pensarse además como uno de los textos producidos en el lenguaje imaginario creado por Xul Solar. La creación de lenguajes ficticios es una característica predominante en los grupos de vanguardia. Xul Solar había inventado dos, el "neocriollo" y la "panlengua". Ambos son el resultado de sus estudios de lenguas no europeas y de su análisis de textos cabalísticos. Xul Solar había intentado, a través del lenguaje, establecer conexiones entre la materialidad de los signos escritos y los movimientos celestes del cosmos. Sin embargo, las lenguas artificiales de Xul Solar provienen además de la observación de los cambios que el español había sufrido debido al contacto con

\footnotetext{
${ }^{1}$ Quisiera expresar mi agradecimiento a Tomás Eloy Martínez y Charles Piano por sus valiosos
} comentarios y sugerencias en relación a versiones previas de este artículo. 
lenguas extranjeras. ${ }^{2}$ El Neocriollo es no sólo la alegoría de la transición de un mundo rural a uno tecnológico, sino un manifiesto de vanguardia hecho hombre, un texto-cuerpo productivo que combina los fragmentos de las distintas tradiciones enfrentadas a comienzos de siglo: el Neocriollo es primero Juan Sin Ropa, el último gaucho de la pampa, luego Cocoliche, el inmigrante italiano recién llegado, y finalmente el abuelo Sebastián. Al escuchar la mención de su nombre el personaje se embarca en una eufórica danza combinatoria de los diversos bailes folclóricos argentinos o bien emite un "chorro de sonidos inarticulados” a la manera de los pájaros que habitan las distintas regiones del país. La noción de hibridez que plasma la descomunal figura del Neocriollo puede pensarse desde las experiencias de cosmopolitismo e inmigración que caracterizan a la vanguardia argentina. Sin embargo, leída desde la clave de los medios masivos, la noción de hibridez combinatoria de este personaje se puede interpretar no sólo desde la influencia de los movimientos artísticos europeos como el cubismo o el surrealismo, sino también desde una nueva lógica que Walter Benjamin denomina la "nueva experiencia” de lo masivo. El Neocriollo es un hombre-máquina que recombina y reproduce desde su exagerado aparato sensorial las nóveles sensaciones urbanas. Durante las primeras décadas del siglo xx la relación entre la materialidad de los procesos corporales y de la palabra escrita se expresa a través de una indagación sobre el rol de los medios en el trabajo creativo. Si se piensa en la escritura como una tecnología del lenguaje, la literatura de las primeras décadas del siglo xx elabora una creciente relación entre la literatura y los medios masivos, en la cual el cine o la radio juegan un papel fundamental. ${ }^{3}$ Para Jesús MartínBarbero, es sólo a través de los medios que la "cultura nacional moderna” de principios del siglo xx logra una representatividad social. En otras palabras, el Neocriollo de Marechal no es sino una réplica de la máquina de los medios y los intentos de grupos intelectuales de procesar las tradiciones híbridas que forman las identidades nacionales a comienzos del siglo xx.

El presente es un estudio sobre representaciones alegóricas similares al Neocriollo en dos novelas argentinas que, aunque distanciadas temporalmente, guardan numerosos elementos en común. Juan Filloy escribe Caterva en 1937 y presenta allí la descripción literaria de los intentos de un grupo de vagabundos y anarquistas por crear una sociedad paralela en el campo argentino. En 1992, Ricardo Piglia retoma la conexión entre anarquismo, máquina y sociedad secreta en una narración ficticia de la vida de Macedonio Fernández junto a anarquistas en un refugio del Delta en La ciudad ausente. Si se revisan las fechas en que fueron escritas Caterva y La ciudad ausente, resultan curiosas no sólo las semejanzas de las circunstancias históricas sino también las similares actitudes de resistencia frente al estado autoritario que adoptaron los intelectuales en ambos períodos. Como señala Nicola Miller, durante las décadas de 1920-1930 y 1970-1980 el campo intelectual argentino sufre profundas afectaciones de forma. En el caso de Argentina las transformaciones se inscriben en el contexto de una larga tradición histórica de confrontación con el poder estatal por ser uno de los países en América Latina de los que el Estado ha intervenido más agudamente en la regulación del campo intelectual. Filloy y Piglia

2 Sobre las creaciones lingüísticas de Xul Solar ver Lindstrom "Xul Solar...”.

${ }^{3}$ Sobre el impacto de los medios en la constitución de los grupos letrados latinoamericanos ver Castillo y Páz-Soldán. 
construyen un modelo de resistencia que reúne la constitución de una sociedad secreta y la producción de un proyecto literario alternativo, en el que la creación de un nuevo lenguaje juega un rol fundamental. Ya sea por la vía de viajes astrales en Caterva o por la ilimitada reproducción de las historias que se insertan en la máquina de La ciudad ausente, la inmaterialidad del discurso literario se presenta como un acto contestatario a las tecnologías del palpable autoritarismo del poder estatal.

La relación entre tecnología y anarquismo a comienzos de siglo xx es evidente más allá de que los nuevos medios como el cine hayan sido resistidos en ciertos sectores ligados al comunismo. Como parte de sus actividades para promover las clases obreras, "La sociedad luz" impartía conferencias sobre ciencias industriales que se complementaban con proyecciones cinematográficas y que luego eran publicadas en el periódico $\mathrm{La}$ Vanguardia (Barrancos, La escena...). Roberto Arlt, quien mantuvo una estrecha conexión con los grupos y autores del anarquismo de comienzos de siglo, plantea en muchos de sus textos la combinación revolucionaria de cuerpo y tecnología. ${ }^{4}$ Ya sea como ficción anarquista en los años veinte y treinta o bien como ficción de resistencia frente a la represión estatal de los años setenta, los textos de Filloy y Piglia ponen en tela de juicio los criterios de verosimilitud por medio de una indagación sobre las conexiones entre cuerpo, escritura y tecnología. En Filloy como en Piglia, el relato policial es el género preferido para desenmascarar las complicidades entre verosimilitud y ficción. La ficción, tal como se presenta en la novela de Piglia, es un mecanismo que activa la reconstrucción de la memoria histórica, al tiempo que señala su artificialidad como una construcción mediática.

Un aspecto final a considerar en ambos autores es el uso de elementos residuales en la composición del trabajo artístico, en lo que se ha denominado la "estética del basurero" (Grzegorcyzk). Tanto en Filloy como en Piglia, la incorporación de los residuos de la historia (personajes-residuos como los linyeras de Filloy o residuos de narraciones como en el museo de Piglia) son mecanismos de creación literaria que al mejor estilo de las vanguardias de los años 1920 y 1930 emplean el collage como estrategia de reciclado para crear originalidad. Al proponer el texto literario como un espacio de reciclado de desechos, ambos autores ponen en cuestionamiento ciertos criterios sobre el estatus de la obra literaria y de la categoría de autor. Más aún, la relación con lo residual expone la conflictiva vinculación entre cuerpo y escritura. La novela de Juan Filloy, centrada en un espacio de marginalidad y delincuencia, se presenta como la alternativa a los cenáculos literarios de Buenos Aires y más aún, los siete vagos de Caterva son los alter-egos de los representantes de los grupos de vanguardia porteños.

Caterva: del Basurero al cosmos

Juan Filloy, el "escritor escondido” como lo denomina la crítica argentina reciente, es autor de una cuantiosa obra que se difundió en su mayor parte en ediciones de autor. En una entrevista concedida a Mónica Ambort, Filloy señala que su negación a publicar

\footnotetext{
${ }^{4}$ Como señala Josefina Ludmer, muchas de las representaciones de Arlt provienen de la tradición cultural anarquista. Sin embargo, Arlt mezcla estas representaciones con las figuras de los medios cinematográficos y literarios presentes en su mundo urbano contemporáneo.
} 
se debió al contenido altamente transgresivo de sus obras y a su temor de que dañaran su rol público de fiscal. Por otra parte, la reacción de Filloy se explica como una forma de resistencia a los círculos editoriales porteños a los que consideraba como “castrados” y plagados de eufemismos. ${ }^{5}$ Esta actitud de sospecha frente a la palabra escrita y las distintas formas por las que se regula es un elemento crucial en la novela. En Caterva (por definición, una multitud de personas o cosas consideradas de menor importancia) siete vagabundos deambulan por el campo cordobés. Sus numerosas performances lingüísticas y corporales, sus proclamas sobre ideales estéticos y sociales a la manera de textosmanifiestos y el continuo debate acerca de su rol en la revolución social futura, son elementos que hacen de este grupo una traslación literaria del movimiento vanguardista. Caterva es un compendio de numerosos géneros. Es por un lado la historia del robo cometido por el grupo contra Freya, la jefa de una cadena de mendigos. Desafiando las convenciones del género policial, la investigación de los pesquisas tiene un carácter secundario y esta primera historia (los pesquisas tratando de apresar al grupo) da lugar a una segunda en la que los mendigos cumplen el rol de investigadores y develan un complot alemán en América del Sur. La novela es además un libro de viajes al estilo de la vanguardia, en el que el viaje funciona como una búsqueda de identidad grupal a través de experiencias sensoriales e incluso metafísicas haciendo una parodia del uso paisajístico del turismo. Caterva es, fundamentalmente, un texto que debate sobre los posibles roles del intelectual en un proyecto de sociedad futura y es por ese carácter virtual que la novela posee un final que es un no-final. El grupo se disuelve porque, al decir de Katanga, uno de los líderes del grupo, el lazo espiritual que los unía ha desaparecido. Por su carácter utópico, tanto el origen como la disolución del grupo se presentan como eventos accidentales que carecen de una explicación en la lógica del relato.

La "caterva” está formada por seres doblemente marginales: todos son extranjeros y prófugos de la justicia o de algún fantasma del pasado. Todos han cambiado su nombre propio por un seudónimo para reinventarse como seres sociales. Katanga es, por ejemplo, el seudónimo de Abd-ul Katar ben Hixem, un mago que tiene varios procesos de estupro. Fortunato es en realidad Jaroslav Kopecky, un antiguo gerente de un banco de Praga que ha cometido un desfalco multimillonario e inculpado a un inocente al fugarse de la justicia. Lon Chaney es, como el actor "de las mil caras", un simulador profesional y un trotamundos que ha viajado por diversos países y ha desempeñado dispares oficios: fotógrafo en Haití, gamonal en Ecuador y espía en distintos países. Longines es un relojero suizo que trama distintas artimañas de escape cuando el grupo se ve asediado por las autoridades, un criptógrafo que disfruta de armar y desarmar lenguajes en clave. Viejo amor es un italiano idealista que hace versos, un sujeto libidinoso siempre en búsqueda de un prostíbulo. Los dos personajes restantes son Dijunto, un personaje simple incapaz de comprender las claves y los juegos mentales de Longines y Katanga, y Aparicio, un

\footnotetext{
5 “Es que hasta el año 30 en la República Argentina había una literatura castrada, llena de eufemismo. Y bueno, en los libros de Benito Lynch, de Noel, de Güiraldes, aparecen paisanos refinados, que piden perdón cuando dicen 'verijas'; por poco no hablan en francés... Se denigra así al personaje, haciéndolo hablar con purismos: se lo degenera, se lo desnaturaliza. En mi obra Balumba hay un capítulo que se llama Libídine, donde las putas hablan como lo hacen las putas. ¿Cómo quieren que hablen? ¿Cómo una primera dama de teatro, como una catedrática? No es posible” (52).
} 
agitador profesional uruguayo que se da ínfulas de figura de importancia política. Los líderes del grupo, Longines y Katanga, son seres antagónicos que debaten constantemente sobre su rol en la revolución social futura. Mientras que Longines sostiene que el dinero es el motor de la revolución popular, Katanga es un idealista para quien el dinero sólo sirve para razones ultraístas. La oposición entre materialismo e idealismo que representan estos dos personajes marca resonancias de una larga tradición entre los intelectuales latinoamericanos que Rama ha descrito en detalle en La ciudad letrada. La tensión entre los intereses materiales y espirituales del grupo de Caterva expresa en una representación literaria la vacilación que durante décadas han sufrido los intelectuales en las sociedades latinoamericanas acerca de su participación como agentes de cambio social. Como señala Rama, el período de 1890 a 1920 es un período en el que los intelectuales buscan definir su rol bajo la perspectiva de un liderazgo de índole espiritual que supere las limitaciones del rol político. En el caso de Caterva, esta tendencia idealista se plasma en el ideario anarquista que sirve de elemento vertebral del grupo.

Como reseña Dora Barrancos en su artículo sobre “Anarquismo y sexualidad”, los anarquistas de comienzos del siglo xx celebran la abstinencia, renuncian al consumo y buscan la creación de una sociedad igualitaria basada en el amor fraternal entre los hombres. En Caterva, Katanga, el líder del grupo, materializa tales ideales. Katanga considera el celibato como la condición necesaria para establecer una sociedad futura hecha de iguales, una utopía que en la novela tiene lugar en el campo, reinventando una vez más el mito de la gauchesca de la asociación entre amistad masculina y mundo rural. La confrontación entre espiritualismo y materialismo que plasma el ideario anarquista se materializa en la novela en largos debates sobre el cuerpo y sus funciones fisiológicas. Los diálogos entre los personajes reflejan el deseo de crear espacios inmateriales, utópicos, que trasciendan los basurales y sitios marginales en que se mueven los vagabundos. La exuberancia verbal de los debates de Caterva, acompañada de grandilocuentes gestos y ruidos corporales, hace de estos pasajes ejemplos de las performances que llevaban a cabo los grupos de vanguardia, y expresa un interés por conectar procesos corporales y lingüísticos. Durante las primeras décadas del siglo xx, el cuerpo se vuelve el centro de atención de escritores y artistas en un momento que Tim Armstrong califica como de alta exploración de tecnologías que median entre el cuerpo y la producción de discurso. Los debates de Caterva expresan la tensión entre modelos encontrados de producción literaria, dos de los cuales se hacen presentes en la imagen del autor como un ser orgánico, una producción corporal y la concepción de que el autor es un ser “desencarnado”, un artífice o un ingeniero de la máquina -su obra- para quien la técnica es lo fundamental. La producción y consumo del texto literario se asocian a metáforas que emplean los procesos corporales de ingesta, digestión y eliminación de los alimentos. ${ }^{6}$

\footnotetext{
${ }^{6}$ Ver al respecto el capítulo de Armstrong sobre la cuestión de los desechos corporales, "Waste products” (42-74). Considero significativa la siguiente referencia al concepto de la lectura de James: "James himself commented, in 'The Art of Fiction', that it was the naive reader who thought that 'a novel is a novel, as a pudding is a pudding, and that our only business with it could be to swallow it'. Yet how it is made, and swallowed, and digested is a different matter, in which rumination becomes a metaphor for the art of fiction and the science of criticism; for a kind of consumption which might be moderated within a discipline like Fletcherism” (57).
} 
El discurso de Katanga sobre la importancia de una buena alimentación se inserta curiosamente en una sección en la que, luego de haberse indigestado con comida en mal estado, los personajes de la "caterva” sufren la experiencia de un viaje astral colectivo. Alojados en una pensión en Rumipal, y perseguidos por la mala voluntad de la casera española y las chinches de los cuartos donde van a dormir, el grupo decide sacar los catres al patio donde sufren la transformación debido a las "influencias de la luna llena”, de acuerdo con la interpretación de Katanga. En el viaje, que reelabora el motivo del descenso a los infiernos en manos de una "vorágine" gigantesca, los siete miembros de la caterva se transforman en un "homo septuplex" al tiempo que el tamaño y la forma corporal se ven afectados dramáticamente: "Iban gigantizados. Acromegalizados. Superantropomorfizados. Con la hipófisis viscosa, carbunclosa, truculentamente embutida en la serenidad inexistente de la frente” (182). Con sus cuerpos imantados por la influencia lunar los personajes llegan a "un gran receptáculo”, un "superbuilding de la peste y el morbo. Tallado en la roca viva de todos los cadáveres ostentaba la altura del porvenir y la amplitud de los siglos” (183). Allí contemplan no sólo el grotesco espectáculo de los cadáveres en descomposición sino también una serie de escenas que ejemplifican cada uno de los pecados capitales. El descenso al infierno no es sino un descenso al mundo de los instintos en que los personajes liberan sus energías sexuales reprimidas. El deseo sexual tienen la forma de "nacionalismo subconsciente” al decir de Katanga (209). Ciertas tendencias irracionalistas del período explican el argumento de Katanga al tiempo que fundamentan la vinculación espiritual del grupo. ${ }^{7}$ Katanga contrapone la idea de "amor" a la de "deseo":

Desde entonces supo que, si el amor es un instinto universal, el deseo es una apetencia condicionada en misteriosas fronteras interiores. Cada peregrino, cada proscripto, cada trashumante, por más que quiera arrasarlas, es una antena ansiosa de su patria. Imperceptibles razones inclinan, atraen, atan. No es la lengua, la raza, la idiosincrasia, del otro ser, sino la nostalgia común y la comunidad del recuerdo que brotan en los corazones distantes. Acercándose, se acercan a ella. Uniéndose, viven los mismos latidos y las mismas efusiones en la conjunción de los sentimientos nativos. (209-10)

La importancia del deseo y de los fenómenos psíquicos en Caterva expresa una consciente decisión de suprimir la materialidad corporal a fin de trascender el individualismo y alcanzar una unión espiritual con los restantes miembros de la "caterva”. Las numerosas referencias a los viajes astrales de Katanga, la escena de un velorio en que el cuerpo magnético se eleva del cuerpo material, las continuas menciones de la "imantación” de cuerpos por los poderes energéticos del ambiente, son ejemplos de la obsesión con domesticar los procesos orgánicos para hacer del cuerpo individual un cuerpo cósmico. Estas tendencias "irracionalistas" que tienden a idealizar el origen del grupo en el instinto y niegan la materialidad de las relaciones sociales están en el centro del discurso del

\footnotetext{
${ }^{7}$ Hay otros autores del período que expresan en imágenes similares estas ideas irracionalistas descritas por el personaje de Katanga. Raúl Scalabrini Ortiz construye en El hombre que está solo y espera un personaje que plasma ideales nacionalistas comunitarios. Ver Lindstrom "Scalabrini Ortiz...” y Shumway.
} 
anarquismo y articulan la representación de un "anti-Estado" o "Estado-paralelo". 8 Complementariamente, el complot como forma de sospecha y engaño a distintas formas de autoridad se asienta sobre la base de un lenguaje imaginario, un lenguaje secreto creado a través de la alianza de la caterva. En sus debates acerca de la lengua, los personajes señalan el contenido vital del lenguaje, un contenido alejado de cualquier forma de control autoritario de diccionarios y academias. En relación al nombre propio, el grupo sostiene que es una forma de falsificación de la identidad porque afloja los lazos entre nombres y referentes. Al socavar la base referencial del lenguaje, al proponer la aproximación al lenguaje como un acto esencialmente subjetivo y apartado de cualquier "cosificación" social, la novela propone una disrupción de los fundamentos lingüísticos de las relaciones de poder. El género policial y la construcción de lenguajes artificiales funcionan como ejes de una permanente actitud de sospecha frente a los usos sociales de la palabra.

El mundo de la policía y los ladrones se representa en detalle en numerosas escenas de la novela. Katanga admira a los criminales por representar seres heroicos al tiempo que critica la crónica periodística por la distorsionada presentación que hace del mundo de la delincuencia. Esta descripción del criminal como figura de ribetes románticos permite a los personajes la exaltación de su propia marginalidad. Ellos mismos son prófugos de la ley y sólo consiguen escaparse de la policía por medio de un complejo sistema de claves que Longines diseña para el grupo. En la novela, sin embargo, no es la policía, sino el delincuente, el estafador el que posee la más acabada capacidad analítica. Así, por ejemplo, es por su capacidad de “criptógrafo” que Longines consigue develar un complot alemán en América del Sur. El hecho de que Longines sea un criptógrafo permite revisar las conexiones entre lenguaje y cuerpo desde una perspectiva diferente a la de Katanga. Longines está obsesionado con la materialidad de la palabra. La disección del manuscrito alemán se compara en la novela con una autopsia: “Igual que un cadáver, el complot nazi mostraba su piel tatuada de cientificismo y las entradas fétidas de ambiciones desmedidas. [...] En cada víscera ¡cuántos ‘tejidos de embustes', cuántos 'vasos comunicantes', cuántos nervios educados en la traición del espionaje!” (346). Recurriendo a una figura común en la narrativa policial, el secreto (y la revelación del misterio) se encuentra en el cuerpo de la víctima. En otro nivel de interpretación es sólo en este “escarbar” las entrañas del lenguaje que se logra una significación subversiva de las palabras. En declaraciones de Filloy, la materialidad de la escritura, el deseo recurrente de perfeccionar la tecnología de la palabra escrita está en el centro de toda creación poética. Filloy confiesa haber escrito todas sus obras a mano porque

los dedos son los extremos terminales de un impulso nervioso que viene del cerebro. Prefiero la escritura manual; es más estilística, más refinada. Con la máquina, expeditiva

\footnotetext{
${ }^{8}$ Las tendencias irracionalistas son un nexo entre el anarquismo y los nacionalismos populistas de los años cuarenta. Curiosamente el anarquismo sienta las bases ideológicas para lo que luego será el peronismo. Angel J. Cappelletti señala al respecto que la desaparición del anarquismo en Argentina está motivada por la fundación de partidos comunistas y la aparición de corrientes nacionalistas populistas que llenan el vacío creado en las clases populares por los gobiernos oligárquicos de las primeras décadas del siglo (Rama y Cappelletti, "Prólogo”).
} 
y diáfana, si bien es cierto, todo se agiliza, el estilo se vuelve más seco y pobre. Por eso yo hago primero mis manuscritos y recién entonces los transcribo. (Ambort 77)

La presencia de la muerte, la propia materialización de la consumación corporal es una referencia constante en la novela. El propósito del viaje comunitario se expresa en términos de un exorcismo de la muerte en la "noticia" con la que se abre la novela: "No se busque un carácter agonal a esta deriva de fracasos, que se convierte en milicia astuta, yendo en viaje de turismo al ideal de los demás... Caterva de aventureros sin fatiga, su heroísmo en marcha no procura nada más que vencer a la muerte en la cercana dimisión de la vida” (8). El personaje de Katanga se denomina a sí mismo "catanga bostera... Un bicho que arrastra su bola de excrementos -reflexiones, remembranzas, etcétera- para nutrirse en el invierno de la desolación” (255). En una escena que es sintomática de este proceso, los personajes intentan resucitar a Lon Chaney transmitiéndole ondas de energía, “[o]ndas que pretendían vivificar la psiquis, mientras el médico se obstinaba en salvar la carne. Ondas jay! que se perdieron, como sus afanes, en la ruptura de la bicorporeidad y en el eclipse de la ataraxia” (222). Caterva es una novela que intenta exorcizar el duelo por medio de la escritura. Se trata no sólo del duelo como un hecho diegético, sino fundamentalmente, de la marginación del grupo intelectual cuya alegoría es la “caterva” de vagabundos en la novela, personajes cuyas identidades han sido forzadas o desplazadas. La “caterva” es todo lo que dejó de lado el proyecto centralista de la literatura porteña, un proyecto del que Filloy se había distanciado en forma voluntaria de por vida. Caterva presenta la escritura como una respuesta a los mecanismos de duelo y las experiencias de desplazamiento sufridas por el campo intelectual argentino. Sin embargo, y volviendo a las relaciones entre cuerpo y palabra, Filloy explora tanto en el cuerpo individual como en el cuerpo colectivo de la caterva, las posibilidades creativas de la escritura. En este nivel, Caterva se acerca a La ciudad ausente por una doble vertiente: no sólo propone un modelo de resistencia a los mecanismos de control desde una alianza de intelectuales o una sociedad secreta, sino que plantea posibles intersecciones entre un proyecto de escritura y un proyecto social plasmado en la imagen de un cuerpo colectivo. El texto de Piglia retoma estos cuestionamientos en el concepto de la verosimilitud literaria e indaga los mecanismos de la ficción en las posibles conexiones entre cuerpo, escritura y tecnología. La ciudad ausente utiliza la estética de la caterva, esto es, la estética de lo marginal, la "estética del basurero" que bien describe el texto de Filloy, en una forma textual que acumula residuos de voces, versiones e historias que han sido silenciados por las políticas de la dictadura. La memoria ocupa un rol fundamental en ambos textos porque se presenta como una práctica de exhumación y un acto de homologación colectiva. En La ciudad ausente estos mecanismos buscan recuperar la figura del "desaparecido".

LA CIUDAD AUSENTE: LA MÁQUINA DEL DUELO

Cuando en 1920 muere Elena de Obieta, su esposa, Macedonio Fernández inicia un largo período de residencias transitorias en casas de amigos, hoteles o pensiones de Buenos Aires. Luego de dejar a sus hijos al cuidado de familiares maternos, Macedonio Fernández se dedica a discurrir sobre el tópico de la nulidad o la cesación de la muerte. 
Décadas más tarde, Ricardo Piglia utiliza esta información biográfica para escribir una ficción sobre el que habría sido el último acto de devoción de Macedonio hacia Elena: en La ciudad ausente, Macedonio le pide a Russo que lo ayude a construir una máquina, una réplica de Elena, que inmortalice su memoria. Tanto La ciudad ausente como las novelas de Macedonio Fernández Museo de la novela de la Eterna y Adriana Buenos Aires no sólo convocan la reflexión sobre la muerte y las posibilidades del duelo, sino que ponen en el centro de la escena la posible vinculación entre la literatura y los medios. Como tecnología de reproducción mecánica en La ciudad ausente, como masificación de la palabra escrita en las novelas de Fernández, los medios presentan en ambos autores un desafío a los límites y convenciones del lenguaje literario y el rol que el autor desempeña como productor de textos culturales. Piglia da una nueva "vuelta de tuerca" a la historia de amor entre Macedonio y Elena para ubicarla en el contexto de la sociedad argentina de la "postdictadura”. La novela es un intento de explicar los mecanismos de control político en el Estado represor al tiempo que promueve una construcción utópica de la sociedad democrática futura. Así como en Caterva, La ciudad ausente propone la creación de una sociedad alternativa de intelectuales y describe los utópicos textos de resistencia producidos por ellos. Los textos de esta sociedad secreta provienen del cuerpo de esta mujer-máquina, Elena, clara representación de la relación entre tecnología y poder político que la novela de Piglia busca indagar. ${ }^{9}$ La novela intenta, en palabras de Idelber Avelar, la imposible tarea de domesticar el duelo por medio de una máquina que es a la vez funeraria y utópica, réplica de un cuerpo y ausencia de la persona amada. De manera similar a Caterva, la máquina es el objeto en torno al cual se organiza una sociedad paralela que se ubica en un espacio alternativo, en un lugar "fuera de la ciudad", en este caso el Delta del río Paraná. El título de la novela alude no sólo a los mecanismos de la ausencia que concitan los procesos del duelo, sino también al carácter fantasmagórico de la ciudad durante la dictadura. ${ }^{10}$ Ana María Amar Sánchez ha estudiado de qué manera las ciudades se transforman en espacios de diáspora debido al efecto inmaterial de los medios masivos. ${ }^{11}$

${ }^{9}$ Como señala Luis Ernesto Cárcamo Huechante, la transición democrática fue acompañada en las sociedades latinoamericanas del Cono Sur por transformaciones tecnológicas en el área de los medios masivos.

${ }^{10}$ Filmes argentinos recientes han incursionado en la reconstrucción de esta experiencia histórica. Así, Garage Olimpo emplea un realismo fílmico que combina de manera glacial el mundo subterráneo de la cámara de torturas y la exterior pasividad de la ciudad de Buenos Aires. El efecto que se logra es la "evaporación” del espacio visual: la aparente calma cotidiana -las imágenes aéreas de Buenos Aires mostradas con una veracidad casi documental- es una construcción artificialmente lograda sobre la dolorosa sepultura de lo que no se ve. La ciudad de Buenos Aires, aunque presentada con sonidos e imágenes que fácilmente invitan al espectador a identificar espacios y sensaciones cotidianos, se transforma así en una ciudad de fantasmas y zombis.

11 "If media has homogenized experience, it has also made the virtual become familiar, and daily life foreign; it provides the only safe haven in the face of a city which paradoxically feels dangerous and empty at the same time. ... In the post-Pinochet era, the post-Argentine military dictatorship, or the 'Fujimori era,' there is nothing left to look for in these spaces. All possibility of utopia has ended; indeed, the non place is the opposite of utopia. It is interesting to note the paradox created by the displacement of terms: if utopia is the non-place as an imaginary, ideal, or desired space, the non-place is its opposite and is characterized by the lack of any utopian project” (214). 
En La ciudad ausente la dinámica de lo visible e invisible se transforma no sólo en una reflexión sobre el régimen de la dictadura y los mecanismos de control de un "estado telepático", ${ }^{12}$ sino también en una investigación de los mecanismos del relato. El relato y el Estado viven, de acuerdo con La ciudad ausente, en un espacio virtual situado entre lo revelado y lo oculto. Comisionado por el diario El Mundo, Junior debe encontrar la máquina que le envía mensajes cifrados y que Fuyita custodia celosamente en un museo. El museo es la representación más acabada del espacio de virtualidad de la ficción. Cada una de sus salas recrea distintos relatos que Junior va "activando" a medida que recorre el museo. El museo es un espacio donde tiene lugar esta potencialidad narrativa y una cámara que almacena la memoria colectiva de estos relatos infinitos y en este sentido, el museo de La ciudad ausente evidencia los mecanismos de memoria histórica en la era de la televisión por cable, tal como los ha analizado Andreas Huyssen (“Escape...”).

La novela de Piglia conecta la necesidad histórica de la memoria con el debate sobre los medios y su rol en la sociedad de los años noventa. La máquina es un emblema de los medios: produce relatos-imágenes virtuales. La máquina comparte tanto con la política como con el Estado represivo la capacidad para reproducir imágenes y construir una simulación de la realidad. De acuerdo con Russo el Estado basa su poder en la capacidad de controlar las imágenes, mientras que la tortura y otros mecanismos de vigilancia se basan en la analogía de visión y conocimiento:

\begin{abstract}
La inteligencia del Estado es básicamente un mecanismo técnico destinado a alterar el criterio de realidad. Hay que resistir. Nosotros tratamos de construir una réplica microscópica, una máquina de defensa femenina, contra las experiencias y los experimentos y las mentiras del Estado. Ve, dijo, y levantó la mano con un gesto que abarcaba los árboles y las islas ajenas, hay micrófonos y cámaras ocultas y policías por todos lados, todo el tiempo nos vigilan y nos graban y yo no sé si usted mismo es de veras un periodista o si es un espía o las dos cosas a la vez. (142-43)
\end{abstract}

Es imposible ignorar las resonancias de los escritos de Benjamin en esta presentación del dominio tecnológico como un mecanismo perverso del autoritarismo estatal. Sin embargo, la novela de Piglia retoma también las capacidades creativas de la técnica y las condensa en la figura de la máquina como un mecanismo de resistencia y de memoria. La reproducción tecnológica adquiere en los escritos de Benjamin dos formas: es, por un lado, la forma en que circulan imágenes y objetos en la sociedad capitalista, y por ello causa un efecto ilusorio de falsificación; por otro lado, Benjamin señala la potencialidad artística de los medios tecnológicos y la apertura de posibilidades que representa para el productor artístico. La novela de Piglia está poblada de inventores y de máquinas, de autómatas y de científicos dementes. Entre ellos está Ritcher, un ingeniero suizo que se hace pasar por

\footnotetext{
${ }^{12}$ Fuyita dice al respecto: “-El poder político es siempre criminal-dijo Fuyita-. El presidente es un loco, sus ministros son todos psicópatas. El estado argentino es telépata, sus servicios de inteligencia captan la mente ajena. Se infiltran en el pensamiento de las bases. Pero la facultad telepática tiene un inconveniente grave. No puede seleccionar, recibe cualquier información, es demasiado sensible a los pensamientos marginales de las personas, lo que los viejos psicólogos llaman el inconsciente. Ante el exceso de datos, amplían el radio de represión” (63).
} 
alemán y que engaña a Perón haciéndole creer que puede fabricar una bomba nuclear. Macedonio, Ritcher, Russo, una serie de inventores que hacen eco de tantos otros en la literatura argentina, entre ellos la galería de personajes de Arlt. Los científicos y los narradores están conectados por la ficción, señala Russo en una secuencia, y la analogía no es accidental. De acuerdo con Alan Pauls, las máquinas representan en Arlt la producción del lenguaje metafórico y el plan, el complot, el manual de funcionamiento son formas asociadas a la actividad de maquinar, es decir, de ficcionalizar, de burlar la interpretación autorizada, de crear una realidad paralela. Si se lleva a un punto más allá la asociación entre máquina y ficción, se puede decir que la así producida se escribe en una lengua espuria que cuestiona la adhesión a ciertas tradiciones establecidas desde el poder. Sin embargo, la máquina de Arlt, de Macedonio, de Piglia, es un ente que se independiza de su creador, un sistema propenso a las reproducciones que niega la conexión con una conciencia creadora y fractura los lazos con los referentes y el lenguaje. Es una máquina al mejor estilo de las vanguardias de los años veinte, fascinante por su autonomía y aterradora por las potencialidades anárquicas que alberga. Es allí donde residen las utopías y revoluciones producidas en un lenguaje híbrido que copia el idioma de los inmigrantes. La metáfora más acabada de la máquina es aquel inmigrante que lee el español a la perfección pero no puede hablarlo: Renzi relata la historia de Laslo Malamüd, un crítico famoso y profesor de literatura en la Universidad de Budapest cuya traducción del Martín Fierro es memorable pero que no puede hablar una palabra de español. De acuerdo con Renzi la máquina de Macedonio intenta lograr lo mismo que Malamüd: "Contar con palabras perdidas la historia de todos, narrar en una lengua extranjera” (17).

La máquina y sus posibilidades reproductoras ponen en evidencia la fragilidad de las conexiones entre lenguaje y cuerpo, entre lenguaje y referente. La novela es, sin duda, una presentación de utopías lingüísticas entramadas en una construcción de tecnologías narrativas. La acción de producir ficciones comienza como una operación de traducción. La máquina expresa a la perfección la idea del personaje de Macedonio: "La primera obra... anticipa todas las que siguen” (41). Toda ficción es una reproducción, aspecto que se plasma en la novela en la reproducción apócrifa de los relatos de la máquina. Al referir la historia de Malamüd, Renzi señala que las historias de la máquina están por todos lados de la ciudad y que "las hacen en Avellaneda, en talleres clandestinos de la provincia, en los sótanos del Mercado del Plata, en el subte de 9 de Julio” (17). Estas imágenes traen a la memoria la librería de Gaetano, el librero de El juguete rabioso, y su mundo subterráneo de literatura barata y folletinesca. De manera similar, Junior tiene que navegar por este mundo subterráneo donde se reproducen las copias y las versiones falsas para poder llegar a la máquina y descubrir por qué quieren desactivarla:

Había andado por los sótanos del Mercado del Plata, había buscado información en los cementerios de noticias, había hecho transas en los bares del Bajo donde vendían documentos falsos, relatos apócrifos, primeras ediciones de las primeras historias. Su pieza estaba llena de papeles, anotaciones, textos pegados en las paredes. Grabaciones. Buscaba orientarse en esa trama fracturada, entender por qué querían desactivarla. (86)

En este punto la ficción se conecta con la materialidad de lo real: el viaje de Junior por la ciudad y sus espacios es el equivalente a un recorrido por la trama de una ficción 
(la historia de la máquina de Macedonio). La colección de documentos apócrifos, de pistas falsas, es el equivalente al mundo del subte, a los “efectos de realidad” del relato:

Entraba y salía de los relatos, se movía por la ciudad, buscaba orientarse en esa trama de esperas y postergaciones de la que ya no podía salir. Era difícil creer lo que estaba viendo, pero encontraba los efectos en la realidad. Parecía una red, como el mapa de un subte. Viajó de un lado al otro, cruzando las historias, y se movió en varios registros a la vez. $\mathrm{Y}$ ahora estaba en un bar de Retiro, comiendo salchichas y tomando cerveza y esperando ver llegar a la chica del teléfono (87).

La tensión entre el original y las copias se expresa acabadamente en la idea anterior: las copias exponen, por medio de su corrupta materialidad, la vulnerabilidad del concepto de originalidad y la oposición de verdad/mentira sobre la que se funda. En otras palabras, ¿cómo saber a ciencia cierta que es ésta la pista o la interpretación verdadera? ¿Cómo es posible creer que sólo hay un itinerario hacia la verdad? La metáfora máxima de este concepto es el manuscrito de Finnegans Wake que funciona como texto sagrado y texto basurero en la Isla-refugio de anarquistas y exiliados donde vive Russo. La ciudad ausente afirma que no existen ni lenguajes originales ni textos sagrados. En el relato "La isla” (el último de la máquina) se narra cómo es la vida en este refugio utópico del delta en el que la idea de patria no existe y "[e]l concepto de frontera es temporal y sus límites se conjugan como los tiempos de un verbo" (123). En "La isla” se vuelve a escribir uno de los relatos sobre la creación del mundo: "Eva es la serpiente, la mutación interminable, y Adán está solo, siempre ha estado solo. Dice que Dios es la mujer y que Eva es la serpiente. Que el árbol del bien y el mal es el árbol del lenguaje. Recién cuando se comen la manzana empiezan a hablar” (128). La caída equivale a la pérdida del lenguaje:

Muchos creen que el Finnegans es un libro de ceremonias fúnebres y lo estudian como el texto que funda la religión en la isla. El Finnegans es leído en las iglesias como una Biblia y es usado para predicar en todas las lenguas por los pastores presbiterianos y por los sacerdotes católicos. En el Génesis se habla de una maldición de Dios que provocó la Caída y transformó el lenguaje en el paisaje abrupto que es hoy. Borracho, Tim Finnegan se cayó al sótano por una escalera, que inmediatamente pasó de ladder a latter y de latter salió litter y del desorden la letter, el mensaje divino. La carta es encontrada en un vaciadero de basura por una gallina que picotea. Está firmada con una mancha de té y la prolongada permanencia en el basurero ha dañado el texto. Tiene agujeros y borrones y es tan difícil de interpretar, que los eruditos y los sacerdotes conjeturan en vano sobre el sentido verdadero de la Palabra de Dios. La carta parece escrita en todas las lenguas y cambia continuamente bajo los ojos de los hombres. Ese es el Evangelio y el basurero de donde viene el mundo. (133)

La máquina funciona como un depósito de creatividad donde se hallan todos los relatos/lenguajes posibles: es por ello que desconoce completamente la idea de un autor o un lenguaje original (en la máquina todo lenguaje es una traducción, toda palabra es la repetición de otra). Es en este depósito de lo virtual donde se almacena la memoria colectiva, una memoria grabada en la materialidad de un cuerpo. En este sentido, $L a$ ciudad ausente es una reflexión acerca de los mecanismos de la memoria en las sociedades 
totalitarias. En la novela, el personaje de Grete Müller quiere rescatar a Elena, a la "Eva Futura" para evitar que el Estado desactive "los nudos blancos" que "estaban grabados en el cuerpo como una memoria colectiva” (80). De acuerdo con el doctor Arana, uno de los científicos de la novela, los nudos blancos son una memoria de la experiencia colectiva atesorados en un cuerpo: "Todo lo que los lingüistas nos han enseñado sobre el lenguaje está también en el corazón de la materia viviente. El código genético y el código verbal presentan las mismas características. A eso lo llamamos los nudos blancos” (72). La máquina-mujer Elena cumple la doble función de crear un simulacro de la realidad y de ser un mecanismo de la memoria. El inventor de Elena, Russo, crea una máquina que no es sino un cuerpo transformado en productor de textos: la lengua es un espacio de reencarnaciones, dice el relato, y cada expresión lingüística acumula los residuos del pasado. ${ }^{13}$ La máquina es un banco de memoria de todos los relatos del mundo o un banco de datos que atesora los textos secretos, subversivos, allí guardados por los miembros de la resistencia del poder autoritario. Paradójicamente, la máquina funciona como un mecanismo de simulación, y hasta como el epítome de la tortura: Elena no es sino un cuerpo que produce información. No es accidental que la crítica haya leído las paradojas del texto de Piglia desde la manipulación del cuerpo femenino en la cultura tecnológica de los ochenta y noventa en una utilización de estos cuerpos en proyectos políticos y estéticos masculinos que eluden cuestiones de protagonismo y control político por parte de la mujer (Masiello). Sin dudas, los efectos de los medios en este proceso son innegables. Jesús Martín-Barbero señala que hacia los años sesenta, luego del fracaso del desarrollismo y de las promesas de modernización como democratización, los medios se han transformado de mediadores a creadores de simulación y de desactivación de las relaciones sociales. En el período posterior a las dictaduras, la cultura de los medios que tan bien supo explotar el régimen menemista, replica ciertas prácticas de las dictaduras: en una nueva forma de “desaparición”, la cultura de los medios transforma a los ciudadanos en imágenes.

Sin embargo, la novela vuelve a la cuestión del cuerpo y es en su materialidad donde establece los mecanismos de resistencia política y de memoria. Así como abunda en inventores, la novela abunda en "amadas inmortales": la Elena de Macedonio, la Beatriz de Dante, la Anna Livia de Notan, la Evita de Perón. Todas ellas mujeres-máquinas creadas a partir del momento de la muerte, todas ellas máquinas reproductoras que simulan la imagen y la presencia de la mujer amada. El cuerpo de cada una de estas mujeres es un espacio que produce la virtualidad de la ficción ya que toda historia se produce desde el cuerpo de una mujer, según lo entiende Macedonio:

Macedonio siempre estaba recopilando historias ajenas. Desde la época en que era fiscal en Misiones había llevado un registro de relatos y cuentos. "Una historia tiene un corazón simple, igual que una mujer. O un hombre. Pero prefiero decir igual que una mujer”, decía Macedonio, "porque pienso en Scherezade”. (46)

\footnotetext{
13 "En esta teoría de las reencarnaciones se ha fundado la lingüística histórica. La lengua es como es, porque acumula los residuos del pasado en cada generación y renueva el recuerdo de todas las lenguas muertas y de todas las lenguas perdidas y el que recibe esta herencia ya no puede olvidar el sentido que esas palabras tuvieron en los días de los antepasados. La explicación es simple pero no resuelve los problemas que plantea la realidad” (121).
} 
Una primera interpretación podría hacer pensar que La ciudad ausente repite los modelos misóginos que los movimientos de vanguardia europeos y latinoamericanos pusieron en práctica al asociar lo femenino con la creciente importancia que la tecnología, los medios y las masas adquirieron a comienzos de siglo xx. Andreas Huyssen ("Mass Culture...”) ha estudiado en detalle de qué modo los escritores del modernismo europeo asociaron la "alta literatura”, la literatura como producto de una élite con los productores masculinos de cultura, al tiempo que dejaron los textos para ser consumidos, los textos sin “calidad literaria” para el público femenino. Sin embargo, como ha señalado Idelver Avelar para el caso de La ciudad ausente, la máquina no cumple las funciones de una repetición ventrílocua o masturbatoria, sino que la máquina trae la memoria al presente por medio de la combinación de fragmentos de historias y experiencias que han sido desechados o silenciados por el poder estatal. La máquina combina la mímesis (entendida como reproducción mecánica) con el luto. Piglia da una nueva interpretación a la asociación entre mujer y tecnología, al poner en escena el ritual del luto que tradicionalmente se asigna a una mujer. Piglia vuelve a la imagen de la "amada inmortal” para ponerla en el contexto de los sistemas totalitarios. En este nuevo rol, la mujer-máquina es un sujeto productor de memoria y un espacio colectivo de duelo. Más aún, leer este sujeto femenino implica analizar también qué rol tienen los medios en la sociedad post dictadura y cómo se integran los intelectuales a este proceso. No se puede desconocer la perversidad del uso de los medios por los totalitarismos y las economías neoliberales que los sucedieron, pero como recuerda Jesús Martín-Barbero, tampoco se puede leer a los medios como creadores unilaterales de efectos culturales desconectados de otras manifestaciones sociales. La propuesta de Piglia es mucho más compleja que el maniqueísmo de "apocalípticos e integrados”. Piglia regresa a Benjamin en la figura de la mujer máquina para visitar las relaciones entre medios y literatura y las posibilidades que el arte tiene al explotar las nuevas formas de producción y recepción que los medios ofrecen. Al tiempo que las máquinas del Estado son perversas creadoras de simulacros, la mujer máquina de $L a$ ciudad ausente se piensa no sólo desde el perverso paradigma de la reproducción mecánica, sino también desde un espacio en que los medios, combinados con la ficción, se transformen en espacios de resistencia política. La máquina articula y narra el contra relato utópico del Estado autoritario y más aún la novela vuelve al tema de la conspiración literaria y la sociedad secreta, aspectos que conectan la empresa de Piglia con la de Juan Filloy en Caterva. ${ }^{14}$

EsPacios DE RESISTENCIA, MUNDOS VIRTUALES

En una de las escenas de Caterva, mientras espera ser investigado por la policía, Katanga piensa, en los gangsters, héroes del mundo moderno. Sus reflexiones sobre el delito sirven de marco a las reflexiones de esta conclusión:

El delito reside en la miseria general, explotada y mantenida por el bloque de vivillos que detentan el poder y los privilegios ... En tal sentido, frente al amarretismo y la

${ }^{14}$ Sobre el tema de la conspiración literaria ver Berg. 
cobardía de los magnates, que sólo aventuran papeles -ipor carta!-, cifras -ipor telégrafo!- y títulos -ipor radio!-, iqué ejemplo de dignidad ofrecen los gangsters! ¡cuán superlativa es la esplendidad moral de sus actos! ¡cómo llena el alma de gozo el viril espejo de sus proezas! (cursivas en el original 40)

En Caterva y La ciudad ausente, la asociación de sujetos criminales -o bien concebidos como tales desde ciertas esferas oficiales del poder- permite la constitución de una sociedad paralela de carácter utópico. En Filloy, tal asociación tiene características inmateriales al negar, desde el ideario anarquista, la importancia del dinero y su impacto en los procesos sociales. Como propone Katanga los gangsters son héroes modernos porque desconocen el uso capitalista del dinero, aspecto que este personaje asocia con una purificación ritualista del cuerpo. En Caterva esta propuesta contraria al materialismo se plasma en la imagen de un cuerpo cósmico que reúna a los siete vagabundos. Este cuerpo colectivo, inmaterial, puede pensarse también como el proyecto de una sociedad futura de carácter alternativo, ubicada en un espacio rural. Como Sarmiento en “Argirópolis” y Filloy en el campo cordobés, Ricardo Piglia localiza tal modelo de sociedad afuera de la ciudad, en el delta. En Ricardo Piglia la sociedad futura se constituye no por medio del ideario anarquista de los años treinta, sino por una intervención de los medios -el control de las "máquinas"- a fin de establecer una literatura virtual como proyecto alternativo. La idea de marginalidad es pertinente en ambos autores y conviene traer a colación una vez más la estética de "basurero" que se utiliza en ambas novelas. Piglia y Filloy no sólo emplean personajes que viven al margen del orden social establecido, sino que ubican el espacio del no-lugar -el espacio de la utopía- fuera de la ciudad. La técnica para crear la utopía consiste en utilizar todo lo que ha sido dejado de lado por proyectos oficialistas -lo desechable-siguiendo una tradición en que, de acuerdo a la obra homónima de Nicola Miller, los intelectuales latinoamericanos han vivido "bajo la sombra del Estado". Si se entiende el Estado como un conjunto de aparatos y relaciones sociales, Filloy y Piglia buscan construir un espacio social que es intangible por utópico y es a través de la representación alegórica de un cuerpo colectivo, un cuerpo-máquina, un cuerpo virtual, que esta literatura establece la alternativa al cuerpo del Estado, la polis. La cuestión del lenguaje literario resulta central en ambos proyectos. Tanto Piglia como Filloy vuelven al género policial como el ejemplo más sintomático de la ficción. El lenguaje de la literatura comparte con el lenguaje de los criminales la capacidad de establecer capas y capas de espacios virtuales sobre el cuerpo del relato. La noción de un lenguaje en clave, tan propia del mundo criminal, adquiere en Filloy y Piglia la cercanía al mundo de la ficción. En Piglia, esta noción se complementa con elementos tomados de la literatura de vanguardia y la fascinación de los autores de comienzos del siglo xx con el efecto de los medios y la tecnología en la creación de espacios híbridos de contacto cultural. Las utopías de Filloy y Piglia son utopías lingüísticas en cuanto proponen una sociedad alternativa hecha de nuevas formas de comunicación y nuevos criterios de verosimilitud. Una última observación resulta pertinente. En ambos casos, la sociedad paralela se asocia a un cuerpo de carácter comunitario en que se trasciende la materialidad de su forma para crear espacios virtuales que permitan la reescritura de las ficciones establecidas por el Estado. Es innegable que 
las coincidencias históricas que sirven de contexto a ambas novelas tienen que ver con sistemas represivos y autoritarios -la década infame, la dictadura de 1976-1983- y los desplazamientos y censuras que sufrió el campo intelectual argentino en estos períodos. Las sociedades alternativas así presentadas son cuerpos utópicos de delicada precisión orgánica, metáforas del cambiante equilibrio entre el intelectual y la sociedad que le sirve de marco, entre mundos posibles y sus espacios de materialización en la historia. Es en la virtualidad de este espacio intermedio, entre utopía e historia, donde la ficción de Filloy y Piglia se mueven en un devaneo constante.

\section{BiBLIOGRAFÍA}

Amar Sánchez, Ana María. "Deserted Cities: Pop and Disenchantment in Turn-of-theCentury Latin American Narrative”. Latin American Literature and Mass Media. Edmundo Paz-Soldán, Debra A. Castillo, eds. New York: Garland; 2001. 207-21. Ambort, Mónica. Juan Filloy, el escritor escondido. Prólogo de Jorge Torres Rogero. Córdoba, Argentina: Ediciones Op Oloop, 1992.

Armstrong, Tim. Modernism, Technology and The Body. A Cultural Study. Cambridge: Cambridge University Press, 1998.

Avelar, Idelber. The Untimely Present. Postdictatorial Latin American Fiction and the Task of Mourning. Durham and London: Duke University Press, 1999.

Barrancos, Dora. La escena iluminada. Ciencias para trabajadores 1890-1930. Buenos Aires: Editorial Plus Ultra, 1996.

“Anarquismo y sexualidad”. Mundo urbano y cultura popular. Estudios de historia social argentina. Diego Armus, comp. Buenos Aires: Editorial Sudamericana, 1990. 15-37.

Barthes, Roland. "The Death of the Author”. Image, Music, Text. Stephen Heath trad. New York: Hill and Wang, 1977. 142-48

Berg, Edgardo. "La conspiración literaria (sobre La ciudad ausente de Ricardo Piglia)”. Hispamérica 25/75 (1996): 37-47.

Benjamin, Walter. “El autor como productor”. Tentativas sobre Brecht. Iluminaciones III. Prólogo, traducción y notas de Jesús Aguirre. Madrid: Taurus, 1991. 115-34

Cárcamo Huechante, Luis Ernesto. "Mediated Memory: Writing, Photography and Performativity in the Age of the Image”. Latin American Literature and Mass Media. Edmundo Paz-Soldán y Debra A. Castillo, eds. New York: Garland, 2001. 103-16.

Castillo, Debra A. y Edmundo Páz-Soldán. “Beyond the Lettered City”. Latin American Literature and Mass Media. New York, NY: Garland, 2001. 1-18

Filloy, Juan. Caterva. Córdoba, Argentina: Universidad Nacional de Río Cuarto, 1992. Garage Olimpo. Dir. Marco Bechis. Argentina, 1999.

Grzegorcyzk, Marzena. "Discursos al margen: Gombrowicz, Piglia y la estética del basurero”. Hispamérica 25/73 (1996): 15-33

Huyssen, Andreas. "Mass Culture as Woman: Modernism's Other”. After the Great Divide. Modernism, Mass Culture, Postmodernism. Bloomington and Indianapolis: Indiana University Press, 1986. 44-62. 
“Escape from Amnesia: The Museum as a Mass Medium”. Twilight Memories: Making Time in a Culture of Amnesia. New York and London: Routledge, 1995.

Lindstrom, Naomi. Macedonio Fernández. Lincoln, Nebraska: Society of Spanish and Spanish-American Studies, University of Nebraska, 1981.

“Xul Solar: Los principios organizadores de su principio organizador”. Hispamérica 25-26 (1980): 161-64.

Ludmer, Josefina. “Historia de un best-seller: del anarquismo al peronismo”. El cuerpo del delito. Un manual. Buenos Aires: Libros Perfil, 1999. 301-51.

Marechal, Leopoldo. Adán Buenosayres. 2 ed. Buenos Aires: Editorial Planeta, 1997.

Martín-Barbero, Jesús. De los medios a las mediaciones. Comunicación, cultura y hegemonía. México: Ediciones G. Gili, 1987.

Masiello, Francine. "Este pobre fin de siglo: Intellectuals and Cultural Minorities During Argentina's Ten Years of Democracy”. Latin American Postmodernisms. Richard A. Young, ed. Amsterdan, Atlanta: Rodopi, 1997. 239-55.

Miller, Nicola. In the Shadow of the State. Intellectuals and the Quest for National Identity in Twentieth-Century Spanish America. London: Verso, 1999.

Pauls, Alan. “Arlt: la máquina literaria”. Yrigoyen, entre Borges y Arlt. Graciela Montaldo, comp. Buenos Aires: Contrapunto, 1989. 307-20

Piglia, Ricardo. La ciudad ausente. Buenos Aires: Seix Barral, 1995.

Rama, Ángel. La ciudad letrada. Hanover: Ediciones del Norte, 1984.

Rama, Carlos M. y Ángel Cappelletti. El anarquismo en América Latina. Caracas: Biblioteca Ayacucho, 1990.

Shumway, Nicolas. “The Tribal Imagination: Raúl Scalabrini Ortiz’s Reconstruction of the Argentine Tribe That Never Was”. Annals of Scholarship 11/1-2 (1996): 83-101. 